\title{
Effects of dietary omega-3/omega- 6 fatty acid ratios on reproduction in the young breeder rooster
}

\author{
Yun Feng ${ }^{1 \dagger}$, Yu Ding ${ }^{1 \dagger}$, Juan Liu', Ye Tian¹, Yanzhou Yang ${ }^{2}$, Shuluan Guan and Cheng Zhang ${ }^{1 *}$
}

\begin{abstract}
Background: Polyunsaturated fatty acids (PUFAs) are necessary for the body's metabolism, growth and development. Although PUFAs play an important role in the regulation of reproduction, their role in testis development in the rooster is unknown. The present study was conducted to investigate the effects of omega-3/omega- 6 (n-3/n-6, PUFAs) ratios on reproductive performance in young breeder roosters. Plasma levels of reproductive hormones, testis development, and reproductive hormone receptor and StAR mRNA expression were also assessed.

Results: Although PUFAs ( $n-3 / n-6: 1 / 4.15)$ had no significant effect on the testis index ( $P>0.05$ ), the spermatogonial development and germ cell layers were increased. Moreover, serum levels of hormones (GnRH, FSH, LH and T) on day 35 were also significantly increased by PUFAs (n-3/n-6: 1/4.15). To investigate whether PUFAs regulate the expression of hormone receptors and StAR, real time-PCR was used to measure GnRHR, FSHR, LHR and StAR mRNA levels. PUFAs significantly increased the mRNA levels of all of these genes.
\end{abstract}

Conclusions: These results indicate that PUFAs enhance the reproductive performance of young roosters by increasing hormone secretion and function, the latter by up-regulating receptor expression. These findings provide a sound basis for a balanced n-3/n-6 PUFA ratio being beneficial to young rooster reproduction.

Keywords: PUFAs, Young breeder roosters, Reproductive hormones, Testis development, Reproductive hormone receptors, StAR mRNA

\section{Background}

Reproduction is a critical part of poultry production, especially the rooster's reproductive performance. The male gonads, testes secrete androgens and generate sperm, and are vital for males to maintain normal reproductive function. During testis development in the chicken, there is no significant increase in testicular weight from 2 to 15 weeks of age. However, the number of spermatogonia reaches more than one million [1,2]. Spermatogonia provide nutrients for sperm growth and development, and the number of spermatogonia is related to the capacity for testicular spermatogenesis. In addition, the early stage is the most important period for testicular development [3-6].

\footnotetext{
*Correspondence: zhch8012@163.com

${ }^{\dagger}$ Equal contributors

'College of Life Science, Capital Normal University, Beijing 100048, Peoples' Republic of China

Full list of author information is available at the end of the article
}

Polyunsaturated fatty acids (PUFAs) have 16 to 22 carbon atoms and more than one double bond. They have a great impact on reproduction, affecting prostaglandin (PG) synthesis, steroidogenesis, transcription factors and membrane properties [7]. Many studies showed that dietary supplementation with PUFAs, especially omega-3 (n-3) PUFAs, significantly increases sperm fertility in birds $[8,9]$ and boars $[10,11]$. The long-chain n-3 PUFAs eicosapentaenoic acid (EPA; 20:5, n-3) and docosahexaenoic acid (DHA; 22:6, n-3) are especially abundant in natural sources such as fish oils and linseed oil [12]. Spermatogenesis and steroidogenesis of the avian testis depend on many gonadal hormones [13]. PUFAs such as arachidonic acid (AA) and its metabolites affect steroidogenesis through direct effects on steroid acute regulator (StAR) and cytochrome P450, which play a critical role in regulating steroid synthesis [7,14]. Meanwhile, 20-carbon PUFAs are the direct precursors of PGs [15], and participate in the regulation of reproductive endocrinology $[16,17]$.

PUFAs influence the physical nature of cell membranes and are involved in membrane protein-mediated 
responses, lipid mediator generation, cell signaling and gene expression in many different cell types essential for brain and eye development and cardiac health [18]. It is reported that PUFAs may differentially affect cellular responses by changing membrane fluidity, receptor binding characteristics or their downstream activation [19-21]. Several reports suggest that the ratio of omega 6 to omega 3 fatty acids on man diet is approximately 1:1 [22,23]. Moreover, the appropriate ratio of omega6: omega 3 fatty acids affect the reproductive performance of mature cockerels [8].

From 2 to 15 weeks, the growth and maturation of Sertoli and Leydig cells is an important step in early testicular development in the chicken [4]. Although n-3/n-6 (omega3/omega-6) PUFAs are beneficial to male reproduction capacity, especially sperm quality, the appropriate ratio of n-3/n-6 PUFAs for young roosters' testicular development and reproductive hormones was not known. The present study aimed to evaluate the effects of n-3/n-6 PUFAs ratios on testis development in young cockerels (10 to 15 weeks of age), and to investigate the possible mechanism of testis development regulation.

\section{Methods}

\section{Materials}

All reagents were purchased from Sigma Chemical Co. (St. Louis, MO, USA) unless otherwise specified. The ELISA kit was obtained from Nanjing Jian Cheng Bioengineering Institute (Nanjing, Jiangsu, China). Trizol reagent was obtained from Takara Bio, Takara Holdings Inc. (Otsu, Shiga, Japan). The M-MLV Reverse Transcriptase kit was purchased from Omega Bio-Tek, Inc. (Norcross, GA, USA). Soybean oil (SO) and flaxseed oil (FO) were purchased from Xin Yuan (Beijing) Fragrance Technology Co., Ltd.

\section{Animal treatment}

Seventy-day-old Jing Hong breeder roosters (Beijing, China) were selected from the same batch and housed in cages individually under controlled environment conditions (light $13 \mathrm{~h} /$ dark $11 \mathrm{~h}, 22^{\circ} \mathrm{C}$ ). The roosters were fed with dry powder feed and were given free access to feed and water. The present study was performed in accordance with the Guidelines for the Care and Use of Laboratory Animals and the China Council on Animal Care and was approved by the Institutional Animal Care and Use Committee of Capital Normal University.

The breeder roosters were randomly divided into five groups (six roosters per group at 0 days). All birds were fed diet 1 for 7 days and then received different ratios of $n 3 / n 6$ PUFAs [1/18.39 (Treatment 1), 1/7.84 (Treatment 2), 1/ 5.04 (Treatment 3), $1 / 4.15$ (Treatment 4) and $1 / 2.32$ (Treatment 5)] from SO and FO. The basic formulations of the experimental diets contained n3/n6 PUFAs with different ratios from SO and FO: $2 \%$ SO/0\% FO (Treatment
1), $1.5 \% \mathrm{SO} / 0.5 \% \mathrm{FO}$ (Treatment 2), 1\% SO/1\% FO (Treatment 3), $0.5 \% \mathrm{SO} / 1.5 \% \mathrm{FO}$ (Treatment 4 ) and $0 \% \mathrm{FO} / 2 \%$ SO (Treatment 5). The fatty acid compositions of the oils used in this study are presented in Table 1 and the fatty acid compositions of the diets are shown in Table 2 .

\section{Collection of blood and testis samples}

Blood and testis samples were collected at 21 and 35 days after treatment. Blood samples were collected by cardiac puncture [24] and were centrifuged at $3000 \mathrm{rpm}$ for $10 \mathrm{~min}$ at $4^{\circ} \mathrm{C}$ to isolate plasma. Plasma was stored at $-20^{\circ} \mathrm{C}$ until assayed for reproductive hormones.

The birds were decapitated, and their body and testis weights were measured to determine the testis index (testis weight/body weight) [1]. One of the testes was fixed in formaldehyde and embedded in paraffin. The other was stored at $-80^{\circ} \mathrm{C}$ for RT-PCR assay.

\section{Histologic sections}

Testes were fixed, dehydrated through a graded series of ethanol solutions and xylene, and embedded in paraffin. Testes embedded in paraffin were serially sectioned to a thickness of 3-5 $\mu \mathrm{m}$ and placed on slides coated with polyL-lysine. The sections were stained with hematoxylin and eosin (HE) for morphological observation [1].

Table 1 Fatty acid composition of soybean oil and linseed oil (\%)

\begin{tabular}{|c|c|c|}
\hline Fatty acids & Soybean oil & Linseed oil \\
\hline $\mathrm{C} 14: 0$ & 0.11 & 0.04 \\
\hline C15:0 & 0.02 & 0.02 \\
\hline C16:0 & 11.86 & 5.87 \\
\hline C16:1 & 0.14 & 0.06 \\
\hline C18:0 & 4.74 & 4.49 \\
\hline C18:1 & 21.60 & 22.30 \\
\hline C18:3 n-6 & 52.58 & 16.67 \\
\hline C18:3 n-3 & 7.65 & 49.85 \\
\hline$C 20: 0$ & 0.25 & 0.12 \\
\hline$C 20: 1$ & 0.19 & 0.16 \\
\hline$C 20: 3$ n-6 & - & - \\
\hline$C 20: 3$ n-3 & - & 0.06 \\
\hline $\mathrm{C} 22: 0$ & 0.36 & 0.10 \\
\hline$C 22: 1$ & 0.11 & 0.06 \\
\hline C24:0 & 0.07 & 0.03 \\
\hline Others & 0.30 & 0.15 \\
\hline Total & 100.00 & 100.00 \\
\hline n-3 PUFAs & 7.65 & 49.91 \\
\hline n-6 PUFAs & 52.58 & 16.67 \\
\hline$n-3 / n-6$ & $1: 7.34$ & $1: 0.33$ \\
\hline
\end{tabular}

The values were determined by feed analysis test. 
Table 2 Fatty acid composition of diets (\%)

\begin{tabular}{|c|c|c|c|c|c|}
\hline $\begin{array}{l}\text { Fatty } \\
\text { acids } \\
\end{array}$ & $\begin{array}{l}\text { Treatment } \\
1\end{array}$ & $\begin{array}{l}\text { Treatment } \\
2\end{array}$ & $\begin{array}{l}\text { Treatment } \\
3\end{array}$ & $\begin{array}{l}\text { Treatment } \\
4\end{array}$ & $\begin{array}{l}\text { Treatment } \\
5\end{array}$ \\
\hline C14:0 & 0.05 & 0.01 & 0.02 & 0.02 & 0.02 \\
\hline C15:0 & 0.03 & 0.03 & 0.03 & 0.03 & 0.03 \\
\hline C15:1 & 0.02 & - & - & - & - \\
\hline C16:0 & 14.48 & 14.67 & 13.74 & 13.03 & 13.15 \\
\hline C16:1 & 0.14 & 0.13 & 0.14 & 0.13 & 0.14 \\
\hline C18:0 & 3.12 & 3.34 & 2.99 & 3.35 & 3.26 \\
\hline C18:1 & 23.58 & 25.63 & 23.91 & 23.29 & 24.13 \\
\hline $\begin{array}{l}\mathrm{C} 18: 2 \\
n-6\end{array}$ & 53.93 & 48.53 & 48.19 & 47.40 & 40.38 \\
\hline $\begin{array}{l}C 18: 3 \\
n-3\end{array}$ & 2.93 & 6.20 & 9.58 & 11.42 & 17.47 \\
\hline C20:0 & 0.43 & 0.44 & 0.38 & 0.37 & 0.37 \\
\hline C20:1 & 0.28 & 0.29 & 0.28 & 0.31 & 0.32 \\
\hline $\begin{array}{l}C 20: 3 \\
n-6\end{array}$ & 0.04 & 0.04 & 0.06 & 0.09 & 0.14 \\
\hline $\begin{array}{l}C 20: 3 \\
n-3\end{array}$ & - & - & - & - & - \\
\hline C22:0 & 0.27 & 0.24 & 0.20 & 0.19 & 0.18 \\
\hline C23:0 & 0.14 & 0.06 & 0.05 & 0.04 & 0.03 \\
\hline C22:1 & 0.15 & 0.10 & 0.18 & 0.14 & 0.16 \\
\hline C24:0 & - & - & - & - & - \\
\hline Others & 0.42 & 0.29 & 0.25 & 0.19 & 0.22 \\
\hline Total & 100.00 & 100.00 & 100.00 & 100.00 & 100.00 \\
\hline $\begin{array}{l}n-3 \\
\text { PUFAs }\end{array}$ & 53.97 & 48.57 & 48.25 & 47.49 & 40.52 \\
\hline $\begin{array}{l}\text { n-6 } \\
\text { PUFAs }\end{array}$ & 2.93 & 6.20 & 9.58 & 11.42 & 17.47 \\
\hline$n-3 / n-6$ & 1:18.39 & $1: 7.84$ & 1:5.04 & 1:4.15 & $1: 2.32$ \\
\hline
\end{tabular}

The values were determined by feed analysis test.

\section{Measurement of reproductive hormones}

The plasma concentrations of gonadotropin-releasing hormone $(\mathrm{GnRH})$, luteinizing hormone $(\mathrm{LH})$, folliclestimulating hormone (FSH) and testosterone (T) were measured using an ELISA kit (Nanjing, Jiangsu, China) according to the manufacturer's instruction. All assays were performed in 96-well plates and the absorbance was measured at $450 \mathrm{~nm}$ (BioTek Instruments, Inc., Winooski, USA). A standard curve was used to determine hormone levels.

\section{RNA extraction, CDNA synthesis, and real-time PCR analysis}

Testes were ground in liquid nitrogen, and total RNA was extracted using Trizol reagent according to the manufacturer's instructions. Total RNA was reverse transcribed to cDNA using M-MLV Reverse Transcriptase. Briefly, $0.2 \mu \mathrm{g}$ of total RNA was reverse transcribed in a $20-\mu \mathrm{l}$ reaction containing $4 \mu \mathrm{l}$ of $5 \times$ reaction buffer, $2 \mu \mathrm{l}$ of $10 \mathrm{mM}$
dNTPs, $20 \mathrm{U}$ of RNase inhibitor, $200 \mathrm{U}$ of RevertAid H Minus M-MULV RT enzyme, random decamer primers and RNase-free $\mathrm{H}_{2} \mathrm{O}$. Quantitative PCR analysis of GnRHR, FSHR, LHR, StAR and $\beta$-actin was performed using a LightCycler 2.0 System (Roche Diagnostics).

The GnRHR primers used for amplification were a 5 forward primer (5'- ACGAGCCATGCAGCAGAAG -3') and a 3'reverse primer (5'- CGAACAGTGGAAGGAACCC -3'). The FSHR primer sequences were 5'- CATGTCTCCGGCAAAGCAA -3' (5' forward primer) and 5'- AAAAC GCGTGCCATAATGG -3'(3' reverse primer). The LHR primers used for amplification were a $5^{\prime}$ forward primer $\left(5^{\prime}\right.$ ACTCCTGCGCAAACCCATTC -3') and a 3'reverse primer (5'- CTCGGCTCTTACAGCAACCT -3'). The StAR primer sequences used were a 5 'forward primer (5'- TCAGCCGG CGGATTTAAGG -3') and a 3' reverse primer (5'- TGGTG GCTGCTACAAACACT-3'). $\beta$-actin primer sequences were 5'- AACACCCACACCCCTGTGAT -3' (5' forward primer) and 5'- TGAGTCAAGCGCCAAAAGAA - $3^{\prime}\left(3^{\prime}\right.$ reverse primer).

The reactions were incubated in a 96-well plate at $95{ }^{\circ} \mathrm{C}$ for $5 \mathrm{~min}$, followed by 40 cycles at $95{ }^{\circ} \mathrm{C}$ for $15 \mathrm{~s}$ and $60^{\circ} \mathrm{C}$ for $1 \mathrm{~min}$. Relative mRNA abundance was determined using ABI PRISM 7500 software (Applied Biosystems, Grand Island, NY, USA ). To avoid false-positive signals, dissociation-curve analyses were performed after the amplification and the PCR products were separated on a $1.5 \%$ agarose gel to confirm their sizes. Moreover, the PCR products were purified and sequenced to verify their identities. The results were normalized to the expression levels of $\beta$-actin, a housekeeping gene, by the 2- $\Delta \Delta \mathrm{Ct}$ method [25]. PCR reactions without reverse-transcribed cDNA were used as negative controls. The reactions were conducted in at least duplicate.

\section{Statistical analysis}

Results are presented as means \pm SEM of at least three independent experiments, as detailed in the figure legends. All data were subjected to one way (repeated-measure) ANOVA (Prism 5.0 statistical software; GraphPad Software, Inc., San Diego, CA). Significant differences between treatment groups were determined by the Tukey's test. Statistical significance was defined at $\mathrm{P}<0.05$.

\section{Results}

\section{Effects of $n-3 / n-6$ PUFAs ratios on the testis index}

To evaluate the effect of n-3/n-6 PUFAs on the testis index, various ratios of n-3/n-6 PUFAs were supplied in the diet. Body weight on day 21 tended to increase with increasing ratio of n-3/n-6 PUFAs (Table 3). There were significant differences among treatment $1 / 2$ and treatment $3 / 4(\mathrm{P}<0.05)$. However, weight was not significantly increased with the highest ratio compared with the control group. Although testis weight and testis index increased in a dose-dependent 
Table 3 Effects of different ratios of N-3/N-6 PUFAs on the testes index

\begin{tabular}{lllllll}
\hline Time & Treatment & Body weight(kg) & Left testis weight(g) & Right testis weight(g) & Testis weight(g) & Testis index \\
\hline $21 \mathrm{~d}$ & 1 & $1.2157 \pm 0.0779^{\mathrm{a}}$ & $0.2463 \pm 0.0289$ & $0.2610 \pm 0.0291$ & $0.5740 \pm 0.1245$ & $0.4185 \pm 0.0432$ \\
& 2 & $1.3115 \pm 0.0542^{\mathrm{a}}$ & $0.2883 \pm 0.0339$ & $0.3030 \pm 0.0325$ & $0.4580 \pm 0.1344$ & $0.4483 \pm 0.0315$ \\
& 3 & $1.4752 \pm 0.0139^{\mathrm{b}}$ & $0.3117 \pm 0.0314$ & $0.3223 \pm 0.0364$ & $0.6307 \pm 0.0707$ & $0.4304 \pm 0.0483$ \\
& 4 & $1.3922 \pm 0.0161^{\mathrm{b}}$ & $0.3683 \pm 0.0352$ & $0.3807 \pm 0.0349$ & $0.9063 \pm 0.1492$ & $0.5382 \pm 0.0508$ \\
& 5 & $1.3055 \pm 0.0610^{\mathrm{a}}$ & $0.3637 \pm 0.0562$ & $0.3807 \pm 0.0544$ & $0.7443 \pm 0.1107$ & $0.5648 \pm 0.0622$ \\
$35 \mathrm{~d}$ & 1 & $1.5703 \pm 0.0504$ & $0.8743 \pm 0.0239$ & $0.8904 \pm 0.0211$ & $1.7647 \pm 0.0451$ & $1.1276 \pm 0.0610$ \\
& 2 & $1.5948 \pm 0.0431$ & $0.8890 \pm 0.0191$ & $0.9103 \pm 0.0136$ & $1.7993 \pm 0.0321$ & $1.1294 \pm 0.0298$ \\
& 3 & $1.5680 \pm 0.0264$ & $0.8882 \pm 0.0078$ & $0.9025 \pm 0.0134$ & $1.7907 \pm 0.0208$ & $1.1428 \pm 0.02678$ \\
& 4 & $1.6027 \pm 0.0440$ & $0.9050 \pm 0.0128$ & $0.9317 \pm 0.0093$ & $1.8367 \pm 0.0218$ & $1.14789 \pm 0.0371$ \\
& 5 & $1.5797 \pm 0.0170$ & $0.8923 \pm 0.0482$ & $0.9167 \pm 0.0673$ & $1.8090 \pm 0.0113$ & $1.1423 \pm 0.0058$ \\
\hline
\end{tabular}

Testis index = testis weight $(\mathrm{g}) /$ body weight $(\mathrm{kg})$.

In the same column, values with different small letter superscripts mean significant difference $(P<0.05)$.

manner, there were no significant differences among treatments on day $35(\mathrm{P}>0.05)$.

\section{Effects of N-3/N-6 PUFAs ratios on testis morphology}

Testis morphology in birds at 21 and 35 days are shown in Figure 1. The seminiferous tubule epithelium and spermatogonia of the underlying epithelial cells developed normally. Although no significant difference in testis morphology was found among treatments, 5-6 layers of germ cells were seen on day 21 in birds given treatment 4 (Figure 1D) and treatments 5 (Figure $1 \mathrm{E}$ ). There were 2-3 layers of germ cells with treatments 1 (Figure 1A) and 2 (Figure 1B) and 3-4 layers with treatments 3 (Figure 1C).

On day 35, 6-7 layers of germ cells were observed in the treatment 5 (Figure 1J). The formation speed of spermatogonial at day 35 was improved with an increase in the ratio of $n-3 / n-6$ PUFAs.

Effects of n-3/n-6 PUFAs ratios on serum hormone levels As shown in Table 4, the concentration of GnRH on day 21 and 35 increased with increasing n-3/n-6 PUFA ratio, but was lower at an n-3/n-6 PUFA ratio of 1/2.32 (treatment 5). The GnRH concentration at 21 and 35 days were significantly higher for treatment 4 compared with the other treatments $(\mathrm{P}<0.05)$. The $\mathrm{LH}$ and $\mathrm{T}$ concentrations on days 21 and 35 and the FSH concentration on day 35 showed similar trends as that for GnRH concentration: the LH, FSH and T concentrations were significantly higher for treatment 4 than for other treatments $(\mathrm{P}<0.05)$. There were no significant differences in FSH concentrations at 21 days.

\section{Effects of n-3/n-6 PUFAs ratios on the mRNA levels of} hormone receptor genes in the testis of breeder roosters The relative mRNA levels of GnRH receptor (GnRHR), FSH receptor (FSHR) and $\mathrm{LH}$ receptor (LHR) in the chicken testis are shown in Figure 2. There were no differences among treatments in GnRHR mRNA expression on day 21
(Figure 2A). However, the mRNA level of GnRH was significantly increased by $n 3 / n 6$ PUFAs, especially an $n 3 / n 6$ ratio of $1 / 4.15$ (Figure $2 \mathrm{~A}$ ).

FSHR expression on day 21 was significantly increased in a dose-dependent manner $(\mathrm{P}<0.001)$ (Figure $2 \mathrm{~B}$ ) and was higher for treatment 4 compared with other treatments. Although treatment 3 significantly decreased FSHR expression on day $35(\mathrm{P}<0.01)$, there were no differences among treatments 1, 2, 4 and $5(\mathrm{P}>0.05)$ (Figure $2 \mathrm{~B}$ ).

The LHR mRNA level was lower for treatment 1 compared with the other treatments on day $21 \quad(\mathrm{P}<0.001)$ (Figure 2C), and was highest for treatment 5 on day 35 $(\mathrm{P}<0.01)$ (Figure $2 \mathrm{C})$. There were no differences among treatments $1,2,3$ and $4(\mathrm{P}>0.05)$.

\section{Effects of n-3/n-6 PUFAs ratios on the mRNA level of the} StAR gene in the testis of breeder roosters

As show in Figure 2D, StAR mRNA expression in the rooster testis on day 21 was not significantly affected by the n-3/n- 6 ratio, although treatments 4 and 5 increased the StAR mRNA level compared with treatment 1 (P >0.05) (Figure 2D). At 35 days, treatments 3, 4 and 5 showed significant increases in StAR mRNA level $(\mathrm{P}<0.001)$ (Figure 2D).

\section{Discussion}

The present study aimed to evaluate the effect of different n-3/n-6 PUFAs ratios on testicular development and reproductive hormones, and to provide the basis for determining the appropriate n-3/n-6 PUFA ratio for young chickens. Previous research on boars [10,11], rats [26] and birds $[8,9]$ showed that consumption of an appropriate ratio of n-3/n-6 PUFAs was beneficial to male reproduction capacity, especially sperm quality. However, the appropriate ratio of n-3/n-6 PUFAs for testicular development and reproductive hormones in young roosters was not known.

Testes of chickens are located in the dorsal abdomen and are oval- or bean-shaped and milky white. Early testicular 


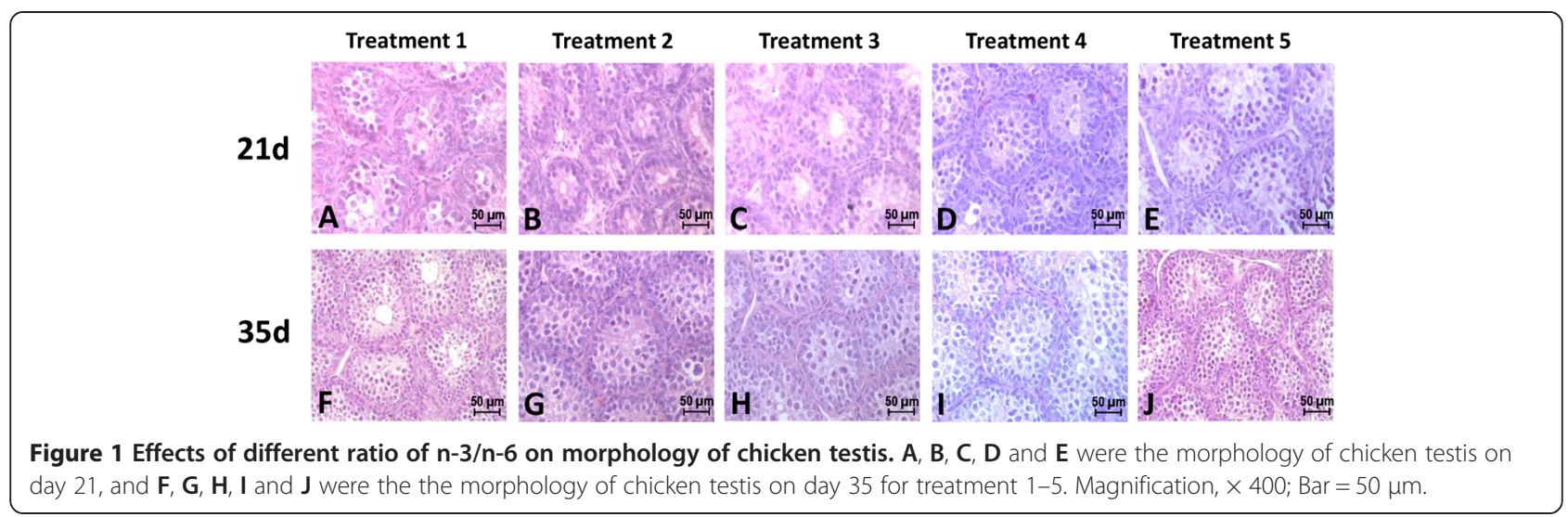

development is crucial to improving the reproductive performance of roosters. From 2 to 15 weeks, the growth and maturation of Sertoli and Leydig cells is the important step in early testicular development in the chicken [4]. These cells facilitate the development of pluripotent PGCs into spermatogonia, which support the germinal cells throughout the life of the bird [27]. The period from 10 to 15 weeks is the key stage for later testicular development. Many studies have shown that testicular growth and development are delayed in underweight chicken $[28,29]$. The ratio of testis weight to total body weight can reflect testis growth. Yan et al. [26] found that a variety of ratios of $n-3 / n-6$ PUFAs had no effect on the testis index in Sprague-Dawley rats. Our study had a similar result for the testis index, although the testis index tended to increase with increasing $n-3 / n-6$ PUFA ratio.

Both $\mathrm{n}-6$ and n-3 PUFAs affect reproduction. Many studies have shown the effects of $n-3 / n-6$ PUFA ratio on male reproduction. $\mathrm{GnRH}$, which is released by the hypothalamus, stimulates release of FSH and LH from the pituitary gland [30]. It is reported that a high-energy diet increased GnRH pulse frequency, testicular weight and sperm production [31]. The study indicated that spermatogenesis and steroidogenesis in the avian testis are dependent on FSH, LH and T [6]. FSH binds to its receptors in the membranes of Sertoli cells, and stimulates spermatogenesis. Testicular function is associated with FSH concentrations in male broiler breeders, and that testis weight is highly correlated with FSH [6]. On the other hand, FSH is necessary for initiation of spermatogenesis and maturation of spermatozoa. Meanwhile, the numbers of spermatogonia, spermatocytes and sperm cells would increase in male monkeys given recombinant human FSH [32]. FSH and LH regulate spermatogenesis via cyclic adenosine 3', 5'-monophosphate (cAMP) [33]. LH binds to receptors in the membranes of Leydig cells, and stimulates the secretion of $\mathrm{T}$. $\mathrm{T}$ levels determine the testicular development and behavior of roosters [26,31]. $\mathrm{T}$ may act on the Sertoli and peritubular cells of the seminiferous tubules and stimulate spermatogenesis [34]. In the present study, we showed that the concentrations of GnRH, FSH, LH and T were positively related to the quality and morphology of sperm. Similarly, Yan et al. [26] reported that the concentrations of GnRH, FSH, LH and T increased with increasing n-3/n-6 PUFA ratio, and that lower and higher $n-3 / n-6$ ratios have opposite effects on reproduction. These results indicate that an appropriate n-3/n-6 PUFA ratio is important for the development of

Table 4 Effects of different ratios of N-3/N-6 PUFAs on the serum hormone levels

\begin{tabular}{llllll}
\hline Time & Treatment & GnRH(ng/L) & LH(mlU/ml) & FSH(IU/L) & T(nmo/L) \\
\hline $21 d$ & 1 & $114.8510 \pm 3.6500^{\mathrm{a}}$ & $2.1117 \pm 0.0816^{\mathrm{b}}$ & $5.3316 \pm 0.0935$ & $9.4830 \pm 0.2194^{\mathrm{a}}$ \\
& 2 & $117.8113 \pm 1.9410^{\mathrm{a}}$ & $2.0503 \pm 0.0245^{\mathrm{ab}}$ & $5.3893 \pm 0.1400$ & $9.5000 \pm 0.1830^{\mathrm{ab}}$ \\
& 3 & $117.9606 \pm 4.5833^{\mathrm{a}}$ & $2.1187 \pm 0.2904^{\mathrm{b}}$ & $5.2857 \pm 0.1560$ & $9.5286 \pm 0.5078^{\mathrm{ab}}$ \\
& 4 & $128.3990 \pm 4.2219^{\mathrm{b}}$ & $2.3397 \pm 0.1090^{\mathrm{b}}$ & $5.5743 \pm 0.2446$ & $10.6810 \pm 0.3215^{\mathrm{b}}$ \\
$35 \mathrm{~d}$ & 5 & $118.7643 \pm 5.0145^{\mathrm{a}}$ & $1.6170 \pm 0.0758^{\mathrm{a}}$ & $5.3740 \pm 0.1878$ & $9.4426 \pm 0.1897^{\mathrm{ab}}$ \\
& 1 & $118.0626 \pm 5.9451^{\mathrm{a}}$ & $2.2897 \pm 0.1448^{\mathrm{a}}$ & $3.8223 \pm 0.0789^{\mathrm{a}}$ & $20.9670 \pm 0.2361^{\mathrm{a}}$ \\
& 2 & $124.7476 \pm 1.7489^{\mathrm{a}}$ & $2.8570 \pm 0.1251^{\mathrm{a}}$ & $4.2557 \pm 0.1354^{\mathrm{a}}$ & $20.8390 \pm 0.4256^{\mathrm{a}}$ \\
& 3 & $120.1923 \pm 3.4892^{\mathrm{a}}$ & $2.7343 \pm 0.1044^{\mathrm{a}}$ & $3.7997 \pm 0.0837^{\mathrm{a}}$ & $21.3133 \pm 0.8362^{\mathrm{ab}}$ \\
& 4 & $136.6667 \pm 3.0792^{\mathrm{b}}$ & $3.4170 \pm 0.1306^{\mathrm{b}}$ & $4.6900 \pm 0.1718^{\mathrm{b}}$ & $23.6027 \pm 0.3857^{\mathrm{b}}$ \\
& 5 & $122.5713 \pm 2.0841^{\mathrm{a}}$ & $2.7203 \pm 0.1524^{\mathrm{a}}$ & $4.3910 \pm 0.3484^{\mathrm{a}}$ & $20.2320 \pm 1.3243^{\mathrm{a}}$ \\
\hline
\end{tabular}

In the same column, values with different small letter superscripts mean significant difference $(P<0.05)$. 


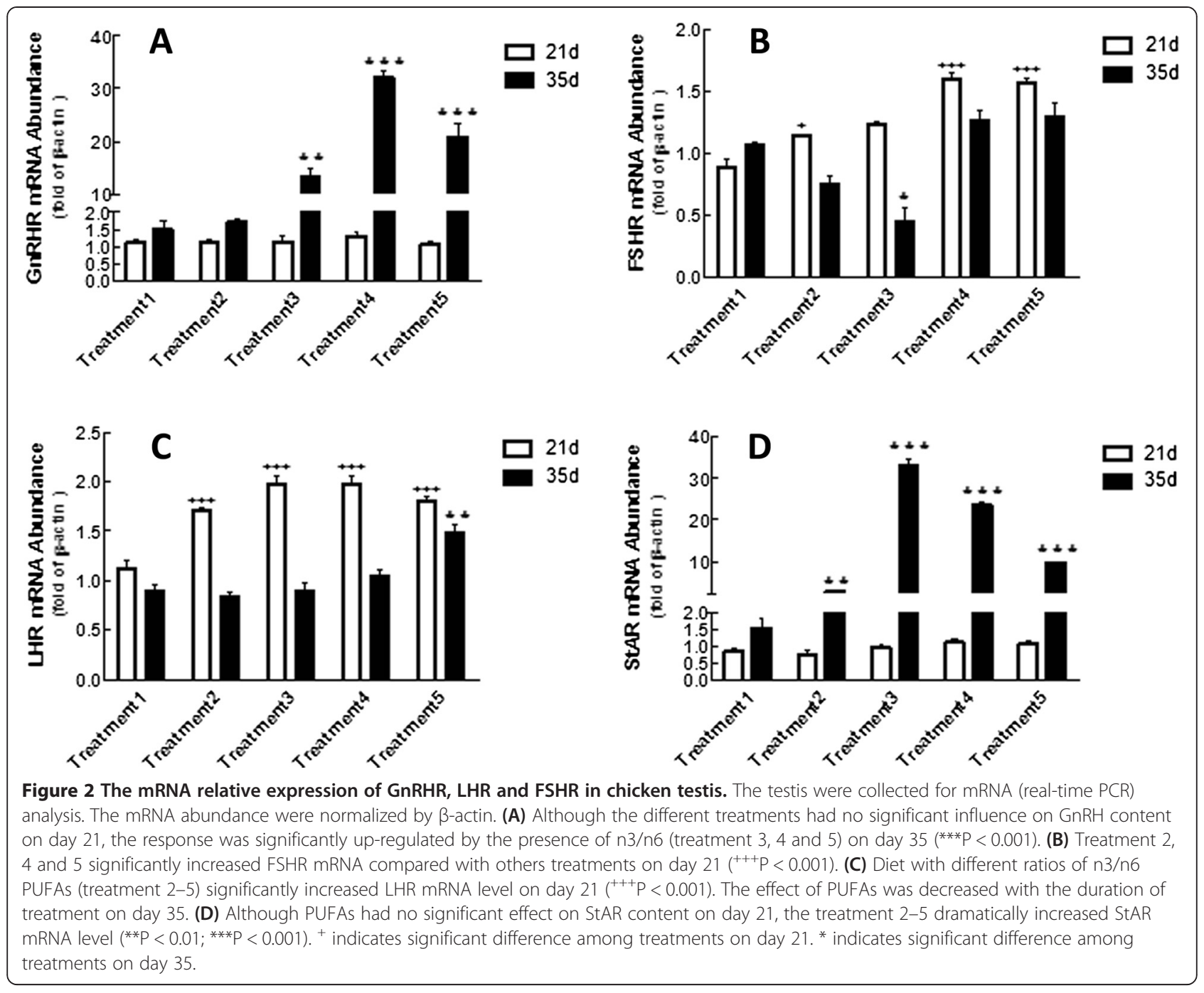

spermatogonia in the rooster. From morphologic analyses of testes, treatments 4 and 5 yielded better histological changes. This suggests that the increased hormone levels improved testis development.

PUFAs act via cell surface and intracellular receptors/ sensors that control cell signaling and gene expression patterns [35]. Some effects of n-3 PUFAs appear to be mediated by, or at least associated with, changes in the fatty acid composition of cell membranes. GnRHR, FSHR and LHR have important roles in the regulation of male reproduction [16,36,37]. In the present study, relative GnRHR, FSHR and LHR mRNA levels at 21 and 35 days differed significantly among ratios of n-3/n-6 PUFAs. This evidence suggests that PUFAs may affect cellular responses through changes in membrane fluidity, receptor binding characteristics or their downstream activation.

StAR promoter activity and StAR mRNA and protein levels in MA-10 Leydig cells were inhibited by inhibition of endogenous AA release, whereas addition of exogenous
AA reversed these effects [16]. On the other hand, specific inhibition of PTGS2 was also associated with increased StAR expression [17]. We found that the relative StAR mRNA level on day 35 differed significantly among ratios of n-3/n-6 PUFAs.

\section{Conclusions}

In conclusion, dietary treatment of roosters with an appropriate n-3/n-6 PUFA ratio (treatment 4: 1/4.15) increased hormone secretion, thereby improving testis development. The treatment also increased reproductive performance, which may be related to changes in the mRNA levels of hormone receptors and StAR. These findings provide a sound basis for a balanced n-3/n-6 PUFA ratio being beneficial to young rooster reproduction.

\section{Abbreviations}

PUFAs: Polyunsaturated fatty acids; DHA: Docosahexaenoic; SO: Soybean oil; LO: Linseed oil; GnRH: Gonadotropin releasing hormone; FSH: Follicular 
stimulating hormone; LH: Luteinizing hormone; T: Testosterone; StAR: Steroid acute regulator protein.

\section{Competing interests}

The authors declared that they have no competing interest.

\section{Authors' contributions}

$\mathrm{CZ}$ conceived and designed the experiments; YF, YD, JL performed the experiments; YD, YT, analyzed the data; SG contributed reagents/materials/ analysis tool; YF, YD wrote the paper. $C Z$ and $Y Y$ revised the manuscript. All authors read and approved the final manuscript.

\section{Acknowledgments}

This work was supported by the grant (PXM2012_014207_0001666) from the Innovation team on Nutrition \& Feedstuff in Poultry Beijing, China, Beijing Municipal Natural Science Foundation (No.5142003) and the National Natural Science Foundation of China (No. 31300958). And this project was also supported by Technology Foundation for Selected Overseas Chinese Scholar, Beijing Municipal Bureau of Personnel, China and Funding project for talent development of Beijing municipality (2013D005016000007). The funders had no role in study design, data collection and analysis, decision to publish, or preparation of the manuscript.

\section{Author details}

${ }^{1}$ College of Life Science, Capital Normal University, Beijing 100048, Peoples' Republic of China. ${ }^{2}$ Key Laboratory of Fertility Preservation and Maintenance, Ministry of Education, Key Laboratory of Reproduction and Genetics in Ningxia, Department of Histology and Embryology, Ningxia Medical University, Ningxia 750004, Peoples' Republic of China.

\section{Received: 4 December 2014 Accepted: 11 March 2015} Published online: 21 March 2015

\section{References}

1. Sarabia Fragoso J, Pizarro Diaz M, Abad Moreno JC, Casanovas Infesta P, Rodriguez-Bertos A, Barger K. Relationships between fertility and some parameters in male broiler breeders (body and testicular weight, histology and immunohistochemistry of testes, spermatogenesis and hormonal levels). Reprod Domest Anim. 2013;48(2):345-52.

2. Anastasiadou M, Theodoridis A, Avdi M, Michailidis G. Changes in the expression of Toll-like receptors in the chicken testis during sexual maturation and Salmonella infection. Anim Reprod Sci. 2011;128(1-4):93-9.

3. Huh MI, Jung JC. Expression of matrix metalloproteinase-13 (MMP-13) in the testes of growing and adult chicken. Acta Histochem. 2012;115(5):475-80.

4. Mucksova J, Brillard JP, Hejnar J, Poplstein M, Kalina J, Bakst M, et al. Identification of various testicular cell populations in pubertal and adult cockerels. Anim Reprod Sci. 2009;114(4):415-22.

5. Silversides FG, Robertson MC, Liu J. Growth of subcutaneous chicken testicular transplants. Poult Sci. 2013;92(7):1916-20.

6. Vizcarra JA, Kirby JD, Kreider DL. Testis development and gonadotropin secretion in broiler breeder males. Poult Sci. 2010;89(2):328-34.

7. Wathes DC, Abayasekara DR, Aitken RJ. Polyunsaturated fatty acids in male and female reproduction. Biol Reprod. 2007;77(2):190-201.

8. Zanini SF, Torres CA, Bragagnolo N, Turatti JM, Silva MG, Zanini MS. Evaluation of the ratio of omega(6: omega3 fatty acids and vitamin $E$ levels in the diet on the reproductive performance of cockerels. Arch Tierernahr. 2003;57(6):429-42.

9. Kelso KA, Cerolini S, Speake BK, Cavalchini LG, Noble RC. Effects of dietary supplementation with alpha-linolenic acid on the phospholipid fatty acid composition and quality of spermatozoa in cockerel from 24 to 72 weeks of age. J Reprod Fertil. 1997;110(1):53-9.

10. Estienne MJ, Harper AF, Crawford RJ. Dietary supplementation with a source of omega-3 fatty acids increases sperm number and the duration of ejaculation in boars. Theriogenology. 2008;70(1):70-6.

11. Strzezek J, Fraser L, Kuklinska M, Dziekonska A, Lecewicz M. Effects of dietary supplementation with polyunsaturated fatty acids and antioxidants on biochemical characteristics of boar semen. Reprod Biol. 2004;4(3):271-87.

12. Nettleton JA. Omega-3 fatty acids: comparison of plant and seafood sources in human nutrition. J Am Diet Assoc. 1991;91(3):331-7.
13. Sofikitis N, Giotitsas N, Tsounapi P, Baltogiannis D, Giannakis D, Pardalidis N Hormonal regulation of spermatogenesis and spermiogenesis. J Steroid Biochem Mol Biol. 2008;109(3-5):323-30.

14. Stocco DM, Wang X, Jo Y, Manna PR. Multiple signaling pathways regulating steroidogenesis and steroidogenic acute regulatory protein expression: more complicated than we thought. Molecular endocrinology (Baltimore, Md. 2005;11:2647-59.

15. Needleman P, Turk J, Jakschik BA, Morrison AR, Lefkowith JB. Arachidonic acid metabolism. Annu Rev Biochem. 1986;55:69-102.

16. Wang XJ, Dyson MT, Jo Y, Eubank DW, Stocco DM. Involvement of 5lipoxygenase metabolites of arachidonic acid in cyclic AMP-stimulated steroidogenesis and steroidogenic acute regulatory protein gene expression. J Steroid Biochem Mol Biol. 2003;85(2-5):159-66.

17. Fiedler EP, Plouffe Jr L, Hales DB, Hales KH, Khan I. Prostaglandin F(2alpha) induces a rapid decline in progesterone production and steroidogenic acute regulatory protein expression in isolated rat corpus luteum without altering messenger ribonucleic acid expression. Biol Reprod. 1999;61(3):643-50.

18. Calder PC, Yaqoob P. Understanding omega-3 polyunsaturated fatty acids. Postgrad Med. 2009;121(6):148-57.

19. Cheng Z, Abayasekara DR, Wathes DC. The effect of supplementation with n-6 polyunsaturated fatty acids on 1-, 2- and 3-series prostaglandin F production by ovine uterine epithelial cells. Biochim Biophys Acta. 2005;1736(2):128-35.

20. Jolly CA, Jiang YH, Chapkin RS, McMurray DN. Dietary (n-3) polyunsaturated fatty acids suppress murine lymphoproliferation, interleukin-2 secretion, and the formation of diacylglycerol and ceramide. J Nutr. 1997;127(1):37-43.

21. Fahrenholz F, Klein U, Gimpl G. Conversion of the myometrial oxytocin receptor from low to high affinity state by cholesterol. Adv Exp Med Biol. 1995;395:311-9.

22. Allen $\mathrm{KG}$, Harris MA. The role of $\mathrm{n}-3$ fatty acids in gestation and parturition. Experimental biology and medicine (Maywood, NJ. 2001;226(6):498-506.

23. Simopoulos AP. Omega-3 fatty acids in health and disease and in growth and development. Am J Clin Nutr. 1991;54(3):438-63.

24. Shang XG, Wang FL, Li DF, Yin JD, Li XJ, Yi GF. Effect of dietary conjugated linoleic acid on the fatty acid composition of egg yolk, plasma and liver as well as hepatic stearoyl-coenzyme A desaturase activity and gene expression in laying hens. Poult Sci. 2005;84(12):1886-92.

25. Livak KJ, Schmittgen TD. Analysis of relative gene expression data using real-time quantitative PCR and the 2(-Delta Delta C(T)) Method. Methods (San Diego, Calif. 2001;25(4):402-8.

26. Yan L, Bai XL, Fang ZF, Che LQ, Xu SY, Wu D. Effect of different dietary omega-3/omega-6 fatty acid ratios on reproduction in male rats. Lipids Health Dis. 2013;12:33.

27. Wilson HR, Waldroup PW, Jones JE, Duerre DJ, Harmds RH. Protein Levels in Growing Diets and Reproductive Performance of Cockerels. J Nutr. 1965;85:29-37.

28. Thurston RJ, Korn N. Spermiogenesis in commercial poultry species: anatomy and control. Poult Sci. 2000;79(11):1650-68.

29. Jones JE, Wilson HR, Harms RH, Simpson CF, Waldroup PW. Reproductive performance in male chickens fed protein deficient diets during the growing period. Poult Sci. 1967;46(6):1569-77.

30. de Kretser DM. Endocrinology of male infertility. Br Med Bull. 1979;35(2):187-92.

31. McGary Brougher S, Estevez I, Ottinger MA. Can testosterone and corticosterone predict the rate of display of male sexual behaviour, development of secondary sexual characters and fertility potential in primary broiler breeders? Br Poultry Sci. 2005;46(5):621-5.

32. Ramaswamy S, Plant TM. Operation of the follicle-stimulating hormone (FSH)-inhibin B feedback loop in the control of primate spermatogenesis. Mol Cell Endocrinol. 2001;180(1-2):93-101.

33. Huang HF, Li MT, Wang S, Pogach LM, Ottenweller JE. Alteration of cyclic adenosine 3',5'-monophosphate signaling in rat testicular cells after spinal cord injury. J Spinal Cord Med. 2003;26(1):69-78.

34. O'Donnell L, McLachlan Rl, Wreford NG, Robertson DM. Testosterone promotes the conversion of round spermatids between stages VII and VIII of the rat spermatogenic cycle. Endocrinology. 1994;135(6):2608-14.

35. Calder PC. Mechanisms of action of (n-3) fatty acids. J Nutr. 2012;142(3):592S-9S.

36. Millar RP, Lu ZL, Pawson AJ, Flanagan CA, Morgan K, Maudsley SR. Gonadotropin-releasing hormone receptors. Endocr Rev. 2004;25(2):235-75.

37. Bortolussi M, Zanchetta R, Belvedere P, Colombo L. Sertoli and Leydig cell numbers and gonadotropin receptors in rat testis from birth to puberty. Cell Tissue Res. 1990;260(1):185-91. 